\title{
The genotypic and phenotypic spectrum of PIGA deficiency
}

\author{
Maja Tarailo-Graovac ${ }^{1,2,3 \dagger}$, Graham Sinclair ${ }^{3,4,6 \dagger}$, Sylvia Stockler-Ipsiroglu ${ }^{3,4,7}$, Margot Van Allen ${ }^{2,7}$, Jacob Rozmus ${ }^{5,7}$, \\ Casper Shyr ${ }^{1,2,3}$, Roberta Biancheri ${ }^{8}$, Tracey Oh ${ }^{2,7}$, Bryan Sayson ${ }^{3,4}$, Mirafe Lafek ${ }^{3,4}$, Colin J Ross ${ }^{1,2,3,7}$, \\ Wendy P Robinson ${ }^{2,7}$, Wyeth W Wasserman ${ }^{1,2,3,7}$, Andrea Rossi ${ }^{9}$ and Clara DM van Karnebeek ${ }^{1,3,4,7^{*}}$
}

\begin{abstract}
Background: Phosphatidylinositol glycan biosynthesis class A protein (PIGA) is one of the enzymes involved in the biosynthesis of glycosylphosphatidylinositol (GPI) anchor proteins, which function as enzymes, adhesion molecules, complement regulators and co-receptors in signal transduction pathways. Until recently, only somatic PIGA mutations had been reported in patients with paroxysmal nocturnal hemoglobinuria (PNH), while germline mutations had not been observed, and were suspected to result in lethality. However, in just two years, whole exome sequencing (WES) analyses have identified germline PIGA mutations in male patients with XLIDD (X-linked intellectual developmental disorder) with a wide spectrum of clinical presentations.
\end{abstract}

Methods and results: Here, we report on a new missense PIGA germline mutation [g.15342986C>T (p.S330N)] identified via WES followed by Sanger sequencing, in a Chinese male infant presenting with developmental arrest, infantile spasms, a pattern of lesion distribution on brain MRI resembling that typical of maple syrup urine disease, contractures, dysmorphism, elevated alkaline phosphatase, mixed hearing loss (a combination of conductive and sensorineural), liver dysfunction, mitochondrial complex I and V deficiency, and therapy-responsive dyslipidemia with confirmed lipoprotein lipase deficiency. X-inactivation studies showed skewing in the clinically unaffected carrier mother, and CD109 surface expression in patient fibroblasts was 57\% of that measured in controls; together these data support pathogenicity of this mutation. Furthermore, we review all reported germline PIGA mutations (1 nonsense, 1 frameshift, 1 in-frame deletion, five missense) in 8 unrelated families.

Conclusions: Our case further delineates the heterogeneous phenotype of this condition for which we propose the term 'PIGA deficiency'. While the phenotypic spectrum is wide, it could be classified into two types (severe and less severe) with shared hallmarks of infantile spasms with hypsarrhythmia on EEG and profound XLIDD. In severe PIGA deficiency, as described in our patient, patients also present with dysmorphic facial features, multiple CNS abnormalities, such as thin corpus callosum and delayed myelination, as well as hypotonia and elevated alkaline phosphatase along with liver, renal, and cardiac involvement; its course is often fatal. The less severe form of PIGA deficiency does not involve facial dysmorphism and multiple CNS abnormalities; instead, patients present with milder IDD, treatable seizures and generally a longer lifespan.

Keywords: Intellectual disability, Epileptic encephalopathy, Hypotonia, Dysmorphism, Multi-organ involvement, Genomics, Intramyelin edema, Glycosylphosphatidylinositol, Lipoprotein lipase, Alkaline phosphatase, Iron

\footnotetext{
* Correspondence: cvankarnebeek@cw.bc.ca

${ }^{\dagger}$ Equal contributors

${ }^{1}$ Centre for Molecular Medicine and Therapeutics, Vancouver, Canada

${ }^{3}$ Treatable Intellectual Disability Endeavour in British Columbia, Vancouver,

Canada

Full list of author information is available at the end of the article
}

\section{Ciomed Central}

(c) 2015 Tarailo-Graovac et al.; licensee BioMed Central. This is an Open Access article distributed under the terms of the Creative Commons Attribution License (http://creativecommons.org/licenses/by/4.0), which permits unrestricted use, distribution, and reproduction in any medium, provided the original work is properly credited. The Creative Commons Public Domain Dedication waiver (http://creativecommons.org/publicdomain/zero/1.0/) applies to the data made available in this article, unless otherwise stated. 


\section{Background}

Glycosylphosphatidylinositol (GPI) is a glycolipid that is synthesized and transferred to proteins in the membrane of the endoplasmic reticulum [1]. Biogenesis of GPI anchored proteins is a conserved post-translational mechanism in eukaryotes and is important for attaching these proteins to the cell membrane, for protein sorting, trafficking, and dynamics [1], and plays an essential role in embryogenesis, neurogenesis, immune responses, and fertilization [2-6]. To date, more than 20 phosphatidylinositol glycan biosynthesis protein (PIG) subclasses have been found to be involved in GPI anchor biosynthesis and remodeling, and more than 150 proteins carry GPI anchors [1]. An increasing number of human diseases have been discovered to be due to mutations in GPI biosynthesis genes.

PIGA (MIM 311770) encodes one of the seven proteins involved in the transfer of $\mathrm{N}$-acetylglucosamine (GlcNAc) from UDP-N-acetylglucosamide (UDP-GlcNAc) to phosphatidylinositol (PI) to form GlcNac-PI [1]. This is the first step of GPI anchor biosynthesis and takes place on cytoplasmic side of the endoplasmic reticulum [1]. The human PIGA gene is located on chromosome Xp22.2. It spans $162 \mathrm{~kb}$ and the longest transcript (NP_002632.1) encodes for a protein of 484 amino acids expressed in a wide variety of tissues including brain, liver, heart, and blood cells [7]. Somatic PIGA mutations had been well documented in PNH [MIM 300818], an acquired hemolytic disease that manifests after clonal expansion of hematopoietic cells with somatic PIGA mutations, where loss of CD55 and CD59 on erythrocytes causes complement-mediated lysis [8-12]. Unlike somatic PIGA mutations, germline mutations had not been observed until recently, and based on experiments in mice [2] and in both murine [13] and human embryonic stem cells [14] it had been proposed that germline PIGA mutations were lethal. In 2012, using an $\mathrm{X}$-chromosome exome next-generation sequencing screen, Biesecker and colleagues identified a PIGA germline nonsense mutation in two siblings with an early epileptic encephalopathy with hypotonia, brain anomalies (myelination abnormalities and a thin corpus callosum), cleft palate, cardiac anomalies and early death [15]. Recently, four additional clinical reports were published on patients with germline PIGA mutations depicting a wide spectrum of phenotypes and clinical diagnoses [7,16-18], including West syndrome [18], Multiple congenital anomalieshypotonia-seizures syndrome 2 (MCAHS2) $[17,18]$ and Ferro-Cerebro-Cutaneous syndrome (FCCS) [16]. Here, we report a male patient with MRI brain abnormalities that resemble those of infants with maple syrup urine disease (MSUD), multi-organ involvement, therapy-responsive dyslipidemia, and reductions of mitochondrial respiratory complexes I and V on Blue Native Gel (BNG) analysis. Using WES, we identified in this patient a new missense
PIGA germline mutation (g.15342986C $>$ T, c.989G $>$ A [NM_002641], [p.S330N]), which will be referred to as c.989G $>$ A (p.S330N). We also review a total of 8 mutations from 9 unrelated families, summarize clinical findings, discuss genotype-phenotype correlations and identify common features that may be used to guide clinical identification of patients with germline PIGA mutations.

\section{Methods}

This study was approved as part of our TIDEX gene discovery project by the Ethics Board of the Faculty of Medicine of the University of British Columbia (UBC IRB approval H12-00067). Parents provided written informed consent for publication of this report.

\section{Case report}

The male index (II:2) was the second child (Figure 1) of non-consanguineous healthy Chinese parents with unremarkable family history. Prenatal ultrasound showed macrosomia and increased nuchal thickness. At 31 weeks 6 days gestation the biparietal diameter (BPD) was $89 \mathrm{~mm}$ (97th centile), head circumference (HC) was $322 \mathrm{~mm}$ (91st centile), abdominal circumference (AC) $330 \mathrm{~mm}$ ( $>99$ th centile), and femur length (FL) was $64 \mathrm{~mm}$ (86th centil) using B.C. Women's Health Centre standard measurements. At 22 weeks 3 days gestation BPD was $59 \mathrm{~mm}$ (89th centile), HC was $215 \mathrm{~mm}$ (81st centile), AC was $213 \mathrm{~mm}$ (>99th centile), and FL $42 \mathrm{~mm}$ (89th centile). Nuchal fold measurement at 20 weeks 3 days was $6.9 \mathrm{~mm}$. Maternal serum alpha-fetal protein (AFP) at 16 weeks 0 days was $49.1 \mathrm{ug} / \mathrm{L}$ which is 1.37 multiples of the mean (MoM). Amniotic fluid AFP was $22.0 \mathrm{mg} / \mathrm{L}$ which is 3.61 MoM (with a risk assessment for open spina bifida of 1:11). Acetylcholinesterase electrophoresis appeared to be normal. Prenatal amniocentesis revealed normal male karyotype $(46, \mathrm{XY})$. The boy was born at 38 weeks by Caesarean section due to breech position with Apgar scores 5 and 9 . His birth weight was $3975 \mathrm{~g}$ (>99th centile), length was $51 \mathrm{~cm}$ ( 75th centile) and head circumference $36.0 \mathrm{~cm}$ (98th centile). Dysmorphism was noted at birth but became more apparent at a later age. Phototherapy was administered during one week for unconjugated hyperbilirubinemia.

The onset of epilepsy was 2.4 months; he had intractable seizures, which were initially classified as infantile spasms (EEG showed modified hypsarrhythmia), evolving one month later to myoclonic seizures (EEG showed suppression-burst-like pattern). He showed acquired microcephaly at 8.7 months with an occipital frontal circumference (OFC) of $43 \mathrm{~cm}$ ( 3rd centile). On examination at 14 months (Figure $1 \mathrm{~A}$ ), our patient showed plagio-brachycephaly with the flattening of the right occiput greater than the left and a prominent right side of the face, giving the appearance of facial asymmetry. 

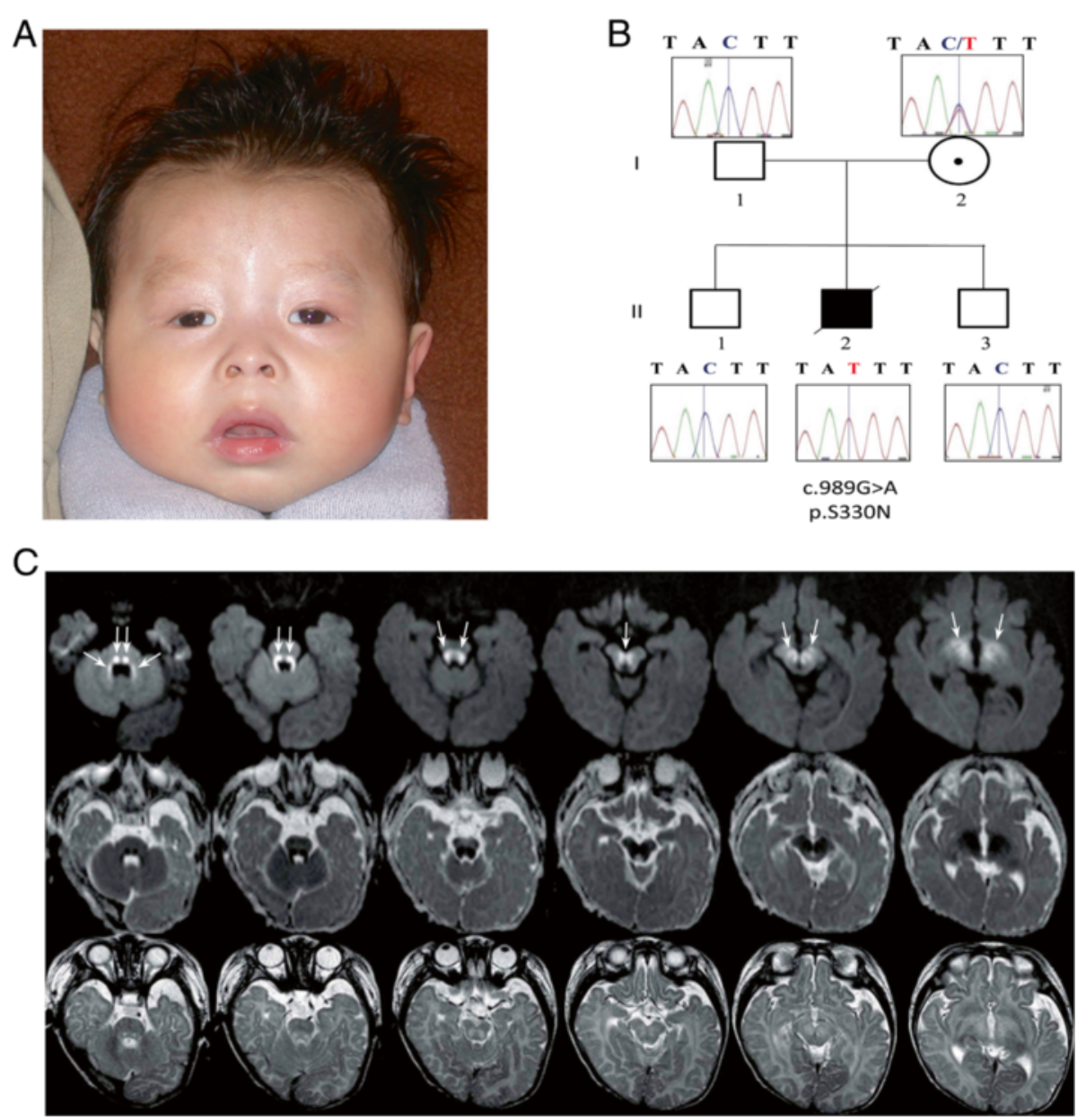

Figure 1 Patient images and pedigree of the family. (A) Facial features of the index patient at age 14 months. (B) Pedigree of the family with new c.989G > A germline PIGA mutation. Sanger sequence verification is shown next to each member of the family. The deceased index was confirmed to be hemizygous for the variant, while mother was confirmed to be a carrier; father and two unaffected brothers were confirmed to

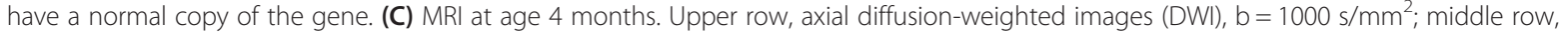
corresponding apparent diffusion coefficient (ADC) maps; bottom row, axial T2-weighted images. There is restricted diffusion, evidenced by high signal on DWI (arrows) and corresponding low signal on the ADC maps, at the level of the ponto-medullary tegmentum, superior cerebellar peduncles, ventral midbrain, subthalamus, and inferior striatum. The same regions show abnormally elevated signal on the T2-weighted images. The abnormalities selectively involve regions that are normally myelinated at this age and are consistent with intramyelin edema.

There was a frontal hair upsweep with unruly scalp hair and poorly defined eyebrows laterally. He had a round face with flattening of the lateral profile, a broad forehead with shallow orbital ridges and supraorbital indentations, most likely due to poor muscle function in the temples. There was glabellar fullness, bilateral ptosis with hypertelorism (intercanthal distance $3.0 \mathrm{~cm} ;+2 \mathrm{SD}$ ), upslanted short palpebral fissures (palpebral fissure length $2.0 \mathrm{~cm} ;-2.0 \mathrm{SD}$ ), and an interpupillary distance of $4.95 \mathrm{~cm}$ (90th centile). The outercanthal distance was $7.0 \mathrm{~cm}(-1 \mathrm{SD})$, within normal limits the short palpebral fissures correct for the hypertelorism. The nose was short $(2.6 \mathrm{~cm} ;-2 \mathrm{SD})$ with a low bridge, prominent lateral nasal cartilage and anteverted nares. Ears were of normal size, placement and form. Philtrum appeared relatively long (measured $1.2 \mathrm{~cm}$ ) and smooth. There was retrognathia, a tented upper lip with thickened alveolar overgrowth giving the appearance of a high arched palate (intact). He showed decreased facial expression. Redundant skin at the neck was noted, along with contractures of the small and large joints of upper and lower extremities; no pigmentation or other cutaneous abnormalities were noted. From a neurologic perspective there was profound global developmental delay with hyperekplexia, axial hypotonia, peripheral hypertonia, rigidity and abnormal cry. There was decreased range of motion of all major joints including the shoulders, elbows, wrist and fingers, as well as hips, knees and ankles. He had hand splints for camptodactyly, deep palmar creases (because of his fisting) and minimal movement of his fingers. 
Brain MRI at presentation (age 4 months) revealed signal abnormalities with restricted diffusion at level of the brainstem tegmentum, superior cerebellar peduncles, subthalamus, and ventral striatum (Figure 1C), while follow-up studies at 10 months and 2.5 years showed progressive, severe cerebral and cerebellar atrophy associated with diffuse leukoencephalopathy and thinning of the corpus callosum. Serial MR spectroscopy showed initially mildly elevated lactate peaks, normal on subsequent imaging, as well as mild reduction of $\mathrm{N}$-acetyl aspartate in the mid brain.

His heart was mildly enlarged and ECG and Holter revealed right ventricular hypertrophy and arrhythmia (AV block, Wenckebach type I). He also had moderate hepatomegaly, apnea, unilateral hydronephrosis with renal calculi, GI dysmotility which led to aspirations requiring G-tube feeding, visual motor impairment and retinal dystrophy (pale optic disc, flat macula, myopia, atrophic retina; no cherry red spot), moderate conductive and sensorineural hearing loss, stomatocytosis and hyperechoic liver. The child died at the age of 3.4 years of cardiac arrest; autopsy was not performed.

TORCH (toxoplasmosis, rubella, cytomegalovirus, herpes simplex, and HIV) screening was negative. A comprehensive metabolic investigation was initiated but largely uninformative, with the following exceptions: Plasma lipid profiling revealed markedly elevated triglycerides at $85.31 \mathrm{mM}$ (reference 0.4-1.5) and cholesterol at $23.4 \mathrm{mM}$ (reference 2.6-5.2), and absent post-heparin lipoprotein lipase activity suggesting a lipoprotein lipase deficiency. The abnormal lipid profile normalized quickly with the implementation of a medium-chain triglyceride enriched diet. Persistently elevated alkaline phosphatase levels were also noted, ranging from 364-649 U/L (Ref 110-320); calcium, phosphate and vitamin $\mathrm{D}$ were within normal limits.

BNG Analysis of a muscle biopsy at 10 months showed decreased amount of complex of I and V (at 30\% and 10\% of a tissue-matched control sample, respectively). These findings led to the initial clinical suspicion of a mitochondrial deficiency syndrome (lactates varied between normal - $3.8 \mathrm{umol} / \mathrm{L}$ ) or lipid storage disorder, and investigations were pursued accordingly.

Further molecular investigations yielded normal results including array-CGH analysis for copy number variations (CNVs), mtDNA genome sequencing, targeted gene sequencing of $L P L, M E C P 2, A R X$ and a number of nuclear encoded mitochondrial proteins. Elaborate biochemical testing was completed with essentially unremarkable results (ammonia, acylcarnitine profile, plasma amino acids, very long chain fatty acids, transferrin isoelectric focussing; urine organic acids, purines \& pyrimidines, mucopolysaccharides, oligosaccharides, bile acids). The following enzymatic analyses yielded normal results: acid phosphatase, sphingomyelinase, arylsulphatase A, hexosaminidase A\&B, biotinidase, chitotriosidase, galactosylceramidase, beta-glucosidase, beta-galactosidase, cathepsin D, palmitoyl protein thio-esterase I, tripeptidyl peptidase I. Filippin staining studies in fibroblasts showed mildly atypical peri-nuclear vesicular accumulations of un-esterified cholesterol but were considered non-diagnostic. Sphingomyelinase enzymology and NPC1 and NPC2 sequencing were all unremarkable. Iron staining of muscle was negative.

\section{Whole exome sequencing}

With a profound IDD and an abnormal biochemical phenotype, this patient met the inclusion requirements for our TIDEX (Treatable Intellectual Disability Endeavour exome sequencing) gene discovery study. We isolated genomic DNA samples from the peripheral blood of the patient as well as parents and two unaffected male siblings using standard techniques. WES was performed for the index patient and his unaffected parents using the Agilent SureSelect kit and Illumina HiSeq 2000 (Perkin-Elmer, Santa Clara, California, USA). An inhouse designed bioinformatics pipeline [19] was used to align the reads to the human reference genome version hg19 and to identify and assess rare variants for their potential to disrupt protein function. The candidate variants were further confirmed using Sanger re-sequencing in all the family members. Deleteriousness of the candidate variants was assessed using Combined AnnotationDependent Depletion (CADD) scores [20], PolyPhen-2 (http://genetics.bwh.harvard.edu/pph2/) [21] and SIFT (Sorting Intolerant From Tolerant; (http://sift.jcvi.org/) [22]. Protein alignment was generated using T-Coffee (http://www.tcoffee.org/) [23] and analyzed using GeneDoc http://www.nrbsc.org/gfx/genedoc/gdpaf.htm/). Only those variants predicted to be "functional" (missense, nonsense and frameshift changes, as well as in-frame deletions and splice-site effects) were subsequently screened under a series of inheritance models.

\section{X-inactivation studies}

$\mathrm{X}$-chromosome inactivation (XCI) was assayed in the unaffected mother using the allelic ratio of methylated alleles at the Androgen Receptor (AR) locus [24] as described previously [25]. The degree of allelic bias in terms of which $\mathrm{X}$ chromosome is inactivated can range from $50 \%$ (completely random) to $100 \%$ (completely skewed).

\section{Functional analysis}

To provide evidence for pathogenicity of the identified mutation, patient and control skin fibroblasts were analyzed by flow cytometry for surface expression of CD109, a GPI-anchored protein. Cells were washed with 
PBS (without $\mathrm{Ca} 2+$ or $\mathrm{Mg} 2+$ ) (Gibco), detached using $5 \mathrm{mM}$ EDTA (Gibco) in PBS and washed in 2\% FBS (Gibco)/PBS. Cells were then stained for 20 minutes at $4^{\circ} \mathrm{C}$ with CD109-PE (BioLegend) and PE mouse IgG1, $\mathrm{K}$ isotype control (BioLegend). Data were acquired using a $\mathrm{BD}^{\mathrm{Ts}}$ LSR II flow cytometer and analyzed using FlowJo v8.8.4 (Tree Star). Protein expression was determined by Western blot analysis. Briefly, skin fibroblasts were harvested and lysed (cell lysis buffer, Cell Signaling) in the presence of protease inhibitor cocktails (Roche). Equal amounts of protein were separated by SDS-PAGE, transferred to PVDF membrane and blocked with 5\% BSA. Protein expression was detected using an anti-PIG-A (clone H-6, Santa Cruz) primary antibody. After washing, bound antibody was detected with HRP-conjugated anti-mouse secondary antibody and Novex ECL chemiluminescent substrate (Invitrogen).

\section{Results}

\section{New PIGA germline mutation in our patient with} multisystem disease

In the WES data we identified four rare homozygous, four rare hemizygous and eight rare compound heterozygous candidates; we did not identify any rare denovo variants affecting protein-coding regions. Of those, only three missense variants were considered functional candidates. COX7A2 (encoding the nuclear-coded polypeptide chains of cytochrome $\mathrm{c}$ oxidase, the terminal oxidase in mitochondrial electron transport (MIM123966)), and C19orf12 (associated with neurodegeneration with brain iron accumulation 4 (MIM 614298)), and Spastic Paraplegia 43 AR (MIM 615043) phenotypes were subsequently ruled out as Sanger sequencing showed the same recessive genotype in both clinically unaffected brothers. The final candidate, PIGA (g.15342986C>T c.989G>A [NM_002641], [p.S330N]) was a novel missense variant not found in more than 250 in-house exomes, dbSNP 138, NHLBI Exome Sequencing Project or Exome Aggregation Consortium (ExAC). The variant is predicted to be the most deleterious of all candidates using the CADD scores [20]. It affects a highly conserved amino acid (Figure 2) and is predicted to be damaging by both PolyPhen-2 [26] and SIFT [22]. The Sanger re-sequencing of the genomic DNA confirmed that index II-2 is hemizygous for the $\mathrm{C}$ to $\mathrm{T}$ transition, mother is the carrier, while the two unaffected brothers do not have this variant (Figure 1B). Finally, X-inactivation studies showed the pattern of X-inactivation to be $94.5 \%$ skewed in the unaffected carrier mother. Together, the genetic analysis based on WES shows that the c.989G>A (p.S330N) variant is a new variant, it affects an evolutionarily conserved amino acid of PIGA resulting in a deleterious change (Figure 2), and segregates with disease in the family (Figure 1B). Functional characterization of the variant showed normal expression of PIGA protein in skin fibroblasts (Figure 3A) but there was a $44 \%$ reduction in the surface expression of GPI-anchored CD109 (Figure 3B). The mother of the patient had a normal complete blood cell count and no evidence of red cell hemolysis on peripheral blood smear. A standardized flow cytometric method for screening PNH measuring CD55 and CD59 expression on erythrocytes was negative.

\section{Discussion}

WES revealed a novel, likely pathogenic variant in the PIGA gene in our patient with multisystem disease including early onset intractable epilepsy, severe IDD, facial dysmorphism, conductive and sensorineural hearing loss and visual impairment, joint contractures and hepatic and renal involvement.

To date, seven germline mutations in PIGA have been discovered using WES technologies in eight unrelated families [7,15-18]. Locations of the pathogenic variants are listed in Table 1 and highlighted on a multi-sequence alignment of PIGA proteins in Figure 2. PIGA germline mutations have been found in XLIDD male patients with a wide spectrum of clinical diagnoses (Table 1). Mothers of the affected males were confirmed to be carriers in all except for one family (Table 1) where the DNA for the mother was unavailable [18].

The phenotypic spectrum of PIGA germline mutations has shown wide variation, as reflected by the range of clinical diagnoses summarized in Table 1. However, a common set of characteristic features, shared by our patient, has emerged including infantile spasms with hypsarrhythmia on EEG (Table 1) and IDD. Generally, the phenotypic spectrum could be classified into two types (severe and less severe), as proposed by Kato et al. [18], where presence of facial dysmorphism correlates very well with the more severe spectrum of clinical manifestations (Table 1). In addition to early onset infantile spasms with hypsarrhythmia on EEG, IDD and profound developmental delay, the patients with more severe manifestations of PIGA germline mutations (patients: IV-2, IV-4 [15], III-1 [17], III-9 [16], 1, 2, and 5 [18], and our case [this report]) also present with dysmorphic facial features, multiple CNS abnormalities, such as thin corpus callosum and delayed myelination, as well as hypotonia (Table 1). Other phenotypes such as polyhydramnios, joint contractures, hyperreflexia, cardiac anomaly, severe developmental delay and elevated alkaline phosphatase are also recurrently seen in these patients, while additional phenotypes appear to be allele-specific (Table 1). Unlike patients with severe phenotypes, the less severe form of PIGA germline mutations (patients: IV-2 [7], 3 and 4 [18]) did not involve facial dysmorphism and multiple CNS abnormalities, but did present with early onset of infantile spasms with hypsarrhythmia on EEG (Table 1), and generally longer life span marked by IDD, treatable seizures and PDD (Table 1). 

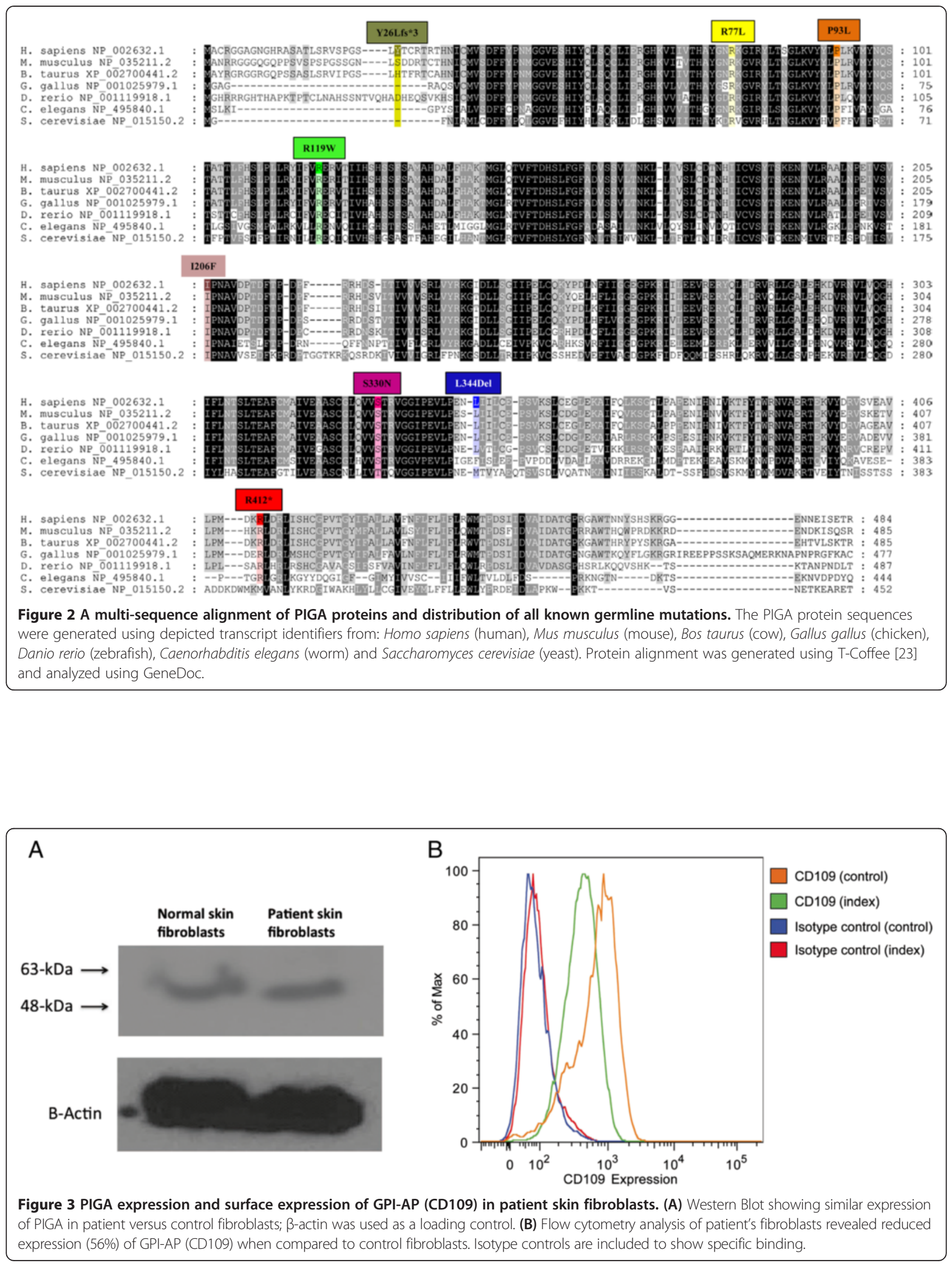
Table 1 Overview of mutations and phenotypes observed in patients with germline PIGA mutations

\begin{tabular}{|c|c|c|c|c|c|c|c|c|c|c|c|}
\hline & $\begin{array}{l}\text { (Johnston } \\
\text { et al. [15]) }\end{array}$ & $\begin{array}{l}\text { (Johnston } \\
\text { et al. [15]) }\end{array}$ & $\begin{array}{l}\text { (van der } \\
\text { Crabben } \\
\text { et al. [17]) }\end{array}$ & $\begin{array}{l}\text { (Swoboda } \\
\text { et al. [16]) }\end{array}$ & $\begin{array}{l}\text { (Belet } \\
\text { et al. [7]) }\end{array}$ & $\begin{array}{l}\text { (Kato } \\
\text { et al. [18]) }\end{array}$ & $\begin{array}{l}\text { (Kato } \\
\text { et al. [18]) }\end{array}$ & $\begin{array}{l}\text { (Kato } \\
\text { et al. [18]) }\end{array}$ & $\begin{array}{l}\text { (Kato } \\
\text { et al. [18]) }\end{array}$ & $\begin{array}{l}\text { (Kato } \\
\text { et al. [18]) }\end{array}$ & Our patient \\
\hline & IV-2 & IV-4 & III-1 & III-9 & IV-2 & 1 & 2 & 3 & 4 & 5 & \\
\hline $\begin{array}{l}\text { Mother } \\
\text { carrier }\end{array}$ & YES & YES & YES & YES & YES & Unknown & YES & YES & YES & YES & YES \\
\hline Mutation & $\begin{array}{l}\text { c. } 1234 C>T \\
{\left[R 412^{*}\right]}\end{array}$ & $\begin{array}{l}\text { c. } 1234 C>T \\
{\left[R 412^{*}\right]}\end{array}$ & $\begin{array}{l}\text { C. } 278 C>T \\
{[P 93 L]}\end{array}$ & $\begin{array}{l}\text { c.328 } \\
\text { 330delCCT } \\
\text { [L344Del] }\end{array}$ & $\begin{array}{l}\text { c.76dupT } \\
\text { [Y26Lfs*3] }\end{array}$ & $\begin{array}{l}\text { c. } 1234 C>T \\
{\left[R 412^{*}\right]}\end{array}$ & $\begin{array}{l}\text { c.616A>T } \\
{[1206 \mathrm{~F}]}\end{array}$ & $\begin{array}{l}\text { c.230G }>\mathrm{T} \\
\text { [R77L] }\end{array}$ & $\begin{array}{l}\text { c.230G }>\mathrm{T} \\
{[\mathrm{R} 77 \mathrm{~L}]}\end{array}$ & $\begin{array}{l}\text { C.355C>T } \\
{[R 119 W]}\end{array}$ & $\begin{array}{l}\mathrm{c.} .989 \mathrm{G}>\mathrm{A} \\
{[\mathrm{S} 330 \mathrm{~N}]}\end{array}$ \\
\hline Polyhydramnios & NO & YES & YES & NO & $\mathrm{NO}$ & YES & NO & NO & $\mathrm{NO}$ & YES & NO \\
\hline Current age & $\begin{array}{l}\text { Death at } \\
11 \text { wk }\end{array}$ & $\begin{array}{l}\text { Death at } \\
\text { 10wk }\end{array}$ & $\begin{array}{l}\text { Death at } \\
2.5 \mathrm{yrs}\end{array}$ & Death at $7 \mathrm{yrs}$ & 24 yrs & 6 yrs & $10 \mathrm{yrs}$ & 8 yrs & $18 \mathrm{mo}$ & $15 \mathrm{mo}$ & $\begin{array}{l}\text { Death at } \\
3.4 \mathrm{yrs}\end{array}$ \\
\hline Sex & M & M & M & M & M & M & M & M & M & M & M \\
\hline \multicolumn{12}{|l|}{ Neurology } \\
\hline $\begin{array}{l}\text { Developmental } \\
\text { delay (severity) }\end{array}$ & Early death & Early death & Profound & Profound & Profound & Profound & Profound & Profound & Profound & Profound & Profound \\
\hline Hypotonia & YES & YES & YES & YES & YES & YES & NO & NO & NO & YES & YES \\
\hline Hyperreflexia & YES & YES & NO & YES & NR & NR & NO & NO & NO & YES & YES \\
\hline Seizure onset & Neonatal & Neonatal & 8.5 months & 7 months & 6 months & 1 month & 3 months & 7 months & 7 months & 3 months & 2.4 months \\
\hline Seizure types & Myoclonic & Myoclonic & $\begin{array}{l}\text { Generalized } \\
\text { clonic } \\
\text { (febrile) }\end{array}$ & $\begin{array}{l}\text { Febrile, } \\
\text { myoclonic }\end{array}$ & $\begin{array}{l}\text { Myoclonic } \\
\text { epileptic } \\
\text { seizures }\end{array}$ & $\begin{array}{l}\text { Tonic seizures } \\
\text { followed by } \\
\text { frequent } \\
\text { myoclonus }\end{array}$ & $\begin{array}{l}\text { Myoclonus } \\
\text { or epileptic } \\
\text { spasm-like } \\
\text { movement }\end{array}$ & $\begin{array}{l}\text { Tonic seizures, } \\
\text { secondarily } \\
\text { generalized } \\
\text { seizures }\end{array}$ & $\begin{array}{l}\text { Tonic or } \\
\text { clonic }\end{array}$ & $\begin{array}{l}\text { Myoclonic } \\
\text { seizures, } \\
\text { tonic spasms }\end{array}$ & $\begin{array}{l}\text { Infantile } \\
\text { spasms, } \\
\text { myoclonic } \\
\text { seizures }\end{array}$ \\
\hline EEG findings & $\begin{array}{l}\text { Suppression } \\
\text { burst }\end{array}$ & $\begin{array}{l}\text { Suppression } \\
\text { burst }\end{array}$ & $\begin{array}{l}\text { Symptomatic } \\
\text { generalized } \\
\text { epilepsy }\end{array}$ & $\begin{array}{l}\text { Posterior } \\
\text { bursts }\end{array}$ & $\begin{array}{l}\text { Hyps- } \\
\text { arrhythmia } \\
\text { at } 7 \mathrm{mo}\end{array}$ & $\begin{array}{l}\text { Suppression } \\
\text { burst at } \\
\text { neonatal } \\
\text { period }\end{array}$ & $\begin{array}{l}\text { Hypsarrhythmia, } \\
\text { periodic bursts } \\
\text { of multifocal } \\
\text { epileptic } \\
\text { discharges }\end{array}$ & $\begin{array}{l}\text { Irregular spike } \\
\text { and slow wave } \\
\text { and multifocal } \\
\text { spikes at } 2 \\
\text { and5 y }\end{array}$ & $\begin{array}{l}\text { Normal } \\
\text { at } 7 \mathrm{mo}\end{array}$ & $\begin{array}{l}\text { Hypsarrhythmia } \\
\text { at } 3 \text { mo, } \\
\text { suppression } \\
\text { burst at } 5 \text { mo }\end{array}$ & $\begin{array}{l}\text { Hypsarrythmia } \\
\text { at } 2.4 \text { mos, } \\
\text { suppression- } \\
\text { burst pattern } \\
\text { at } 3.5 \text { mos }\end{array}$ \\
\hline $\begin{array}{l}\text { Seizure } \\
\text { prognosis }\end{array}$ & Intractable & Intractable & Refractory & Intermittent & NR & Intractable & Intractable & $\begin{array}{l}\text { Seizure-free at } \\
3 \text { y with TPM }\end{array}$ & $\begin{array}{l}\text { Seizure-free } \\
\text { at } 15 \mathrm{mo}\end{array}$ & Intractable & Intractable \\
\hline $\begin{array}{l}\text { Thin corpus } \\
\text { callosum }\end{array}$ & YES & YES & YES & NR & NO & YES & YES & NO & NO & YES & YES \\
\hline $\begin{array}{l}\text { White matter } \\
\text { immaturity }\end{array}$ & YES & YES & YES & NR & NO & YES & YES & NO & NO & YES & YES \\
\hline $\begin{array}{l}\text { Small } \\
\text { cerebellum }\end{array}$ & YES & YES & YES & YES & NO & NR & NR & NR & NR & NR & YES \\
\hline $\begin{array}{l}\text { Cortical } \\
\text { atrophy }\end{array}$ & NR & NR & NR & YES & $\mathrm{NO}$ & YES & YES & $\mathrm{NO}$ & $\mathrm{NO}$ & YES & YES \\
\hline $\begin{array}{l}\text { Restricted } \\
\text { diffusion } \\
\text { brainstem/ } \\
\text { cerebellum }\end{array}$ & NR & NR & NR & NR & NO & YES & YES & NO & NO & YES & YES \\
\hline
\end{tabular}


Table 1 Overview of mutations and phenotypes observed in patients with germline PIGA mutations (Continued)

\begin{tabular}{|c|c|c|c|c|c|c|c|c|c|c|c|}
\hline \multicolumn{12}{|l|}{ Other organs } \\
\hline $\begin{array}{l}\text { Facial } \\
\text { dysmorphism }\end{array}$ & YES & YES & YES & YES & NO & YES & YES & NO & NO & YES & YES \\
\hline $\begin{array}{l}\text { Joints } \\
\text { (contractures) }\end{array}$ & YES & YES & NR & NR & NR & YES & YES & NO & NO & NO & YES \\
\hline Cardiac & $\begin{array}{l}\text { Systolic II-IIINI } \\
\text { murmur with a } \\
\text { fixed split S2, } \\
\text { ASD }\end{array}$ & Small PDA & ASD type 2 & NR & $N R$ & $N R$ & NR & $N R$ & $N R$ & NR & $\begin{array}{l}\text { RVH, } \\
\text { arrhythmia } \\
\text { (grade 1 } \\
\text { AV block, } \\
\text { Wenckebach } \\
\text { type) }\end{array}$ \\
\hline Liver & NR & $\begin{array}{l}\text { Hepatic } \\
\text { microvesicular } \\
\text { steatosis }\end{array}$ & NR & Hepatosplenomegaly & $N R$ & $\begin{array}{l}\text { Hepato-megaly, } \\
\text { hepato-blastoma }\end{array}$ & NR & $N R$ & $N R$ & NR & $\begin{array}{l}\text { Hepatomegaly, } \\
\text { hyperechoic liver }\end{array}$ \\
\hline Kidney & $\begin{array}{l}\text { Vesicoureteral } \\
\text { reflux, } \\
\text { duplicated } \\
\text { collectingSystem }\end{array}$ & $\begin{array}{l}\text { Vesicoureteral } \\
\text { reflux }\end{array}$ & NR & NR & NR & $\begin{array}{l}\text { Vesicoureteral } \\
\text { reflux }\end{array}$ & NR & $N R$ & NR & NR & $\begin{array}{l}\text { Left } \\
\text { hydronephrosis } \\
\text { with renal calculi }\end{array}$ \\
\hline Ophthalmologic & NR & NR & NR & Blindness & $N R$ & $N R$ & NR & $N R$ & $N R$ & NR & $\begin{array}{l}\text { Visual motor } \\
\text { impairment, } \\
\text { retinal } \\
\text { dystrophy }\end{array}$ \\
\hline Hearing loss & NR & NR & NR & Deafness & NR & NR & NR & $N R$ & $N R$ & NR & $\begin{array}{l}\text { Sensorineural } \\
\text { hearing loss }\end{array}$ \\
\hline Dental & NR & $\begin{array}{l}\text { Underdeveloped } \\
\text { gums }\end{array}$ & $\begin{array}{l}\text { Absence } \\
\text { of teeth }\end{array}$ & $\begin{array}{l}\text { NR, but III-10 } \\
\text { microdontia, } \\
\text { widely-spaced, } \\
\text { delayed } \\
\text { eruption }\end{array}$ & NR & $N R$ & NR & $N R$ & NR & NR & $\begin{array}{l}\text { Microdontia, } \\
\text { widely-spaced } \\
\text { delayed eruption }\end{array}$ \\
\hline Other & $\begin{array}{l}\text { Globulous chest } \\
\text { and small nails, } \\
\text { broad palms } \\
\text { with short } \\
\text { fingers }\end{array}$ & $\begin{array}{l}\text { Absence of } \\
\text { olfactory bulb } \\
\text { and tracts }\end{array}$ & $\begin{array}{l}\text { Accelerated } \\
\text { linear } \\
\text { growth, } \\
\text { obesity }\end{array}$ & Ichthyosis & NR & $\begin{array}{l}\text { Tracheostomy, } \\
\text { micropenis, } \\
\text { bilateral inguinal } \\
\text { herniation, } \\
\text { hypotonic } \\
\text { quadriplegia }\end{array}$ & $\begin{array}{l}\text { Spastic } \\
\text { quadriplegia, } \\
\text { bulbar palsy } \\
\text { with } \\
\text { gastrostomy } \\
\text { and } \\
\text { tracheostomy }\end{array}$ & NR & NR & $\begin{array}{l}\text { Transverse } \\
\text { palmar crease, } \\
\text { prominent } \\
\text { calcaneus, left } \\
\text { inguinal hernia, } \\
\text { hydrocele } \\
\text { testicle, } \\
\text { hypotonic } \\
\text { quadriplegia }\end{array}$ & Stomatocytes \\
\hline \multicolumn{12}{|l|}{ Biochemical } \\
\hline $\begin{array}{l}\text { Elevated } \\
\text { alkaline } \\
\text { phosphatase }\end{array}$ & NR & YES & YES & NR & NR & $N R$ & YES & NO & NO & YES & YES \\
\hline $\begin{array}{l}\text { Mitochondrial } \\
\text { abnormalities }\end{array}$ & NR & NR & $\begin{array}{l}\text { Abnormal } \\
\text { ATP } \\
\text { production } \\
\text { (muscle } \\
\text { biopsy) }\end{array}$ & $\begin{array}{l}\text { Disorganized } \\
\text { mitochondria }\end{array}$ & NR & $N R$ & NR & NR & NR & NR & $\begin{array}{l}\text { Respiratory } \\
\text { chain complex I } \\
\text { and V reductions } \\
\text { (muscle blue } \\
\text { native gel) }\end{array}$ \\
\hline Iron storage & NO & NO & NO & $\begin{array}{l}\text { CNS iron } \\
\text { deposition }\end{array}$ & NR & $N R$ & NR & NR & NR & NR & NO \\
\hline
\end{tabular}


Table 1 Overview of mutations and phenotypes observed in patients with germline PIGA mutations (Continued)

\begin{tabular}{|c|c|c|c|c|c|c|c|c|c|c|c|}
\hline Other & $\begin{array}{l}\text { Slightly elevated } \\
\text { MCV and RDW } \\
\text { and low ionized } \\
\text { calcium, } \mathrm{HgB} \\
\text { and RBC }\end{array}$ & $\begin{array}{l}\text { Slightly } \\
\text { elevated MCV } \\
\text { and RDW }\end{array}$ & NO & NR & NR & NR & NR & NR & NR & NR & $\begin{array}{l}\text { Dyslipidemia } \\
\text { (high } \\
\text { triglycerides, } \\
\text { hypercholesterolemia, } \\
\text { LPL deficiency) }\end{array}$ \\
\hline \multicolumn{12}{|l|}{$\begin{array}{l}\text { Clinical } \\
\text { diagnosis }\end{array}$} \\
\hline $\begin{array}{l}\text { Clinical } \\
\text { descriptor }\end{array}$ & $\begin{array}{l}\text { MCAHS2 } \\
\text { Bethesda- } \\
\text { Utrecht } \\
\text { syndrome }\end{array}$ & $\begin{array}{l}\text { MCAHS2Bethesda- } \\
\text { Utrecht syndrome }\end{array}$ & $\begin{array}{l}\text { MCAHS2 } \\
\text { Bethesda- } \\
\text { Utrecht } \\
\text { syndrome }\end{array}$ & $\begin{array}{l}\text { Ferro-Cerebro- } \\
\text { Cutaneous } \\
\text { syndrome }\end{array}$ & $\begin{array}{l}\text { MCAHS2- } \\
\text { like syndrome } \\
\text { X-linked } \\
\text { infantile } \\
\text { spasm } \\
\text { syndrome } \\
\text { (West } \\
\text { syndrome) }\end{array}$ & $\begin{array}{l}\text { Ohtahara } \\
\text { syndrome, } \\
\text { early myoclonic } \\
\text { encephalopathy, } \\
\text { Schinzel-Giedion } \\
\text { syndrome }\end{array}$ & $\begin{array}{l}\text { West syndrome } \\
\text { with } \\
\text { hypomyelination }\end{array}$ & $\begin{array}{l}\text { Early-onset } \\
\text { epileptic } \\
\text { encephalopathy }\end{array}$ & $\begin{array}{l}\text { Early-onset } \\
\text { epileptic } \\
\text { encephalopathy }\end{array}$ & $\begin{array}{l}\text { West } \\
\text { syndrome }\end{array}$ & PIGA deficiency \\
\hline $\begin{array}{l}\text { Cause of } \\
\text { death }\end{array}$ & Pneumonia & Respiratory failure & $\begin{array}{l}\text { Cardiac } \\
\text { arrest }\end{array}$ & $\begin{array}{l}\text { Aspiration } \\
\text { pneumonia }\end{array}$ & NA & NA & NA & NA & NA & NA & Cardiac arrest \\
\hline
\end{tabular}


Early onset infantile spasms appear to be a common feature of PIGA mutations, as is seen with many other defects in GPI-anchor biosynthesis. Chiyonobu et al. [27] hypothesized that these seizures are due to intracellular pyridoxal phosphate deficiency secondary to the loss of membrane bound alkaline phosphatase, which is required to initiate pyridoxal-phosphate for transit of the plasma membrane (after which it is rephosphorylated). Given that GABA synthase requires intracellular pyridoxal-phosphate, it is the intracellular GABA deficiency which likely leads to the onset of seizures [27].

Additional features are frequently reported in patients with the severe form of PIGA germline mutations, as proposed by [18] including: hypotonia (7/8 patients with available data), elevated alkaline phosphatase (5/5 patients with available data), hyperreflexia (5/5 patients with available data), joint contractures (5/6 patients with available data), cardiac anomalies (4/4 patients with available data) and polyhydramnios (4/8 patients with available data) possibly due to dysphagia associated with hypotonia. The plagiocephaly facial dysmorphism in our and published cases is likely secondary to the hypotonia, causing facial asymmetry and distortion of proportions as well as secondary contractures. Our patient specifically appears to have a short nose with anteverted nares and a depressed nasal bridge, seen as the triangular structure at the base of the nose (Figure 1A). This feature appears to be present in the more severely affected published cases [18]. Additional features such as dental problems (e.g. microdontia, delayed eruption) [16,17], liver problems $[15,16,18]$ visual impairment and deafness [16] appear to be recurrent as well (Table 1). On the other hand some features, such as accelerated linear growth and obesity [17], CNS iron deposition and ichthyosis [16], dyslipidemia and stomatocytosis (in the patient reported here) are reported only once. The cause of death in patients with PIGA mutations has been mainly due to cardiac arrest, pneumonia and respiratory failure (Table 1). Although the life span of the patients affected with less severe mutations is generally longer, there is a great degree of variability in life-span even in patients with the same germline mutation $[15,16,18,28]$.

Reports of brain MRI findings in PIGA deficiency describe white matter immaturity with insufficient myelination, cerebral atrophy, thinning of the corpus callosum, and a small cerebellum $[7,15,18]$. Cerebral atrophy appears to progress rapidly and is associated with abnormal white matter myelination, consistent with an early neurodegenerative process [18]. Our case showed a similarly rapid progression, with an established cerebral atrophy associated with disrupted subcortical myelination at age 2.5 years. However, the most remarkable finding in the early stages of the disease was restricted diffusion in the brainstem tegmentum, superior cerebellar peduncles, subthalamus, and ventral striatum, indicative of intramyelin edema, involving selectively white matter regions that are already physiologically myelinated at birth. Kato et al. [18] also reported three cases showing restricted diffusion at the brainstem, basal ganglia, thalamus, and deep white matter. Interestingly, these findings are remarkably similar to those of the classical form of MSUD, an amino aciduria caused by deficiency of branched chain $\alpha$-keto acid dehydrogenase enzyme, in which brain MRI of affected newborns or infants studied during stages of metabolic decompensation shows prominent signal changes and swelling within myelinated brain areas representing intramyelin edema, caused by a deficit of $\mathrm{Na}+/ \mathrm{K}+$ ATPase activity as a result of impairment in energy production secondary to branched chain amino acids accumulation $[29,30]$. In particular, the findings of our case are remarkably similar to those shown in figure six in the report by Rossi and Biancheri [31], implicating that the diagnosis of PIGA deficiency could be suggested in neonates with similar brain MRI findings and unremarkable plasma amino acid and urine organic acid profiles. An explanation for the similarities remains speculative; the typical lesions in the newborn with MSUD involve preferentially those structures that are already myelinated at birth and thus with higher metabolic demands and most vulnerable to the energy deficiency and toxicity of branched-chain 2-oxo acid(s). In PIGA deficiency, although toxins have not yet been identified, we speculate that mitochondrial and thus energy deficiency could similarly play a role in the etiology of the observed intra-myelin edema. Regardless of the implicated pathophysiologic mechanism, identification of similarities in the lesion distribution and appearance on MRI represents the foundation of the pattern recognition approach, whereby neuro-imaging can guide the diagnostic process to reduce the number of unnecessary tests and time to diagnosis [32]. PIGA catalyzes the first step in GPI biosynthesis and it is anticipated that even a partial defect in activity will have a significant impact on the localization and functionality of a broad range of GPI-anchored proteins. The elevation in serum alkaline phosphatase reported here as well as in the majority of other PIGA deficient cases (likely correlated with severity of the disease) (Table 1) as well as other PIG deficiencies results from the secretion of GPI-deficient alkaline phosphatase (normally membrane-anchored) and may serve as a diagnostic clue. Normal levels of alkaline phosphatase however, do not rule out the condition, as evidenced by the mild case reported by Belet et al. [7]. The hypertriglyceridemia and serum LPL deficiency observed in our patient is also likely caused by abnormal GPI biosynthesis. LPL release from endothelial cells in response to heparin stimulation requires the activity of GPIHBP1 (GPI-anchored high-density lipoprotein binding 
protein 1) and primary genetic defects in this GPIanchored protein lead to hypertriglyceridemia and non-detectable serum lipoprotein lipase [33]. The GPI biosynthesis defect resulting from PIGA mutation likely leads to a secondary GPIHBP1 deficiency, although further evaluation is required to confirm this mechanism, as a similar defect has not been described or investigated in other individuals with PIGA defects.

The germline mutational spectrum for PIGA comprises various mutation types including one nonsense mutation $[15,18]$, one frameshift mutation that results in production of 36 amino acids shorter PIGA protein [7], one small in-frame deletion [16], and four missense mutations $[17,18]$ (Figure 2). PIGA protein is well conserved from yeast to human (Figure 2), and all of the reported mutations, except for c.76dupT, occurred at evolutionarily conserved or semi-conserved amino acids (Figure 2). The c.76dupT frameshift mutation occurs in the non-conserved part of the protein but results in translation of the PIGA protein using a cryptic start site at amino acid position 37 producing shorter PIGA protein with the majority of the conserved amino acids intact [7]. One mutation, c. $1234 \mathrm{C}>\mathrm{T}$, was recurrent (Table 1) $[15,18]$.

Studies in mice revealed that complete disruption of the PIGA gene results in early embryonic lethality in males, while in carrier female mice late embryonic lethality is observed [3]. Based on these studies, it is believed that complete loss of PIGA function is lethal in humans. A number of studies suggest that the human mutations identified to date result in reduced, but not absent, PIGA activity and using the flow cytometry of blood granulocytes method, Kato et al. [18] showed that the phenotype severity of the PIGA germline mutations appeared to correlate with genotype and the residual functional activity of the PIGA protein [18]. Functional studies on the truncating c.1234C $>\mathrm{T}$ mutation (p.R412X) suggest that small amounts of full length PIGA protein were generated by the read through of the premature termination codon (PTC) [15,18]. During two stages of eukaryotic translation (elongation and termination), aminoacyltRNAs and termination factors compete for codon binding. When aminoacyl-tRNAs supersedes, read through of the termination codon occurs, which allows the generation of the full-length polypeptide. Depending on the amino acid inserted during the read through, the resulting protein may have normal or partial activity. Studies on base level of read through reveal 10 fold higher frequency at PTCs $(<1 \%)[34,35]$ when compared to naturally occurring stop codons $(<0.1 \%)$ [36,37]. In addition to c.1234C $>\mathrm{T}$ (p.R412X), studies on the c.328_330delCCT (p.L344Del) mutation revealed reduced GPI-anchored proteins on the patient's granulocytes, while normal levels were observed on the red blood cells and monocytes, suggesting reduced but not absent PIGA activity [16]. Complementation assays using the c.76dupT frameshift mutation confirmed partial function of the shorter PIGA protein, which was sufficient to rescue surface expression of CD59 in a PIGA null cell line [7]. Consistent with previous findings, our patient's mutation also led to reduced surface expression of the GPI-anchored protein CD109 on skin fibroblasts, despite normal levels of protein expression.

Patients with PIGA germline mutations share key phenotypic features with patients carrying mutations in genes encoding various PIG family members, including IDD, seizures, hypotonia, growth defects, congenital abnormalities, heart defects, and abnormal metabolic profiles. For example, inherited glycosylphophatidylinositol deficiency (MIM 610293) resulting in portal- and hepatic-vein thrombosis and absence seizures was found to be due to mutations in PIGM gene (MIM610273) [5]. Hyperphosphatasia Mental Retardation syndrome (HPMRS, MIM 239300, MIM 214749, and MIM 614207), also known as Mabry syndrome, was found to be associated with PIGV (MIM 610274), PIGO (MIM 614730),PGAP2 (MIM 615187) and PGAP3 (MIM 611801) mutations [38-42]. HPMRS is characterized by elevated alkaline phosphatase levels, IDD, seizures, hypotonia, and facial dysmorphic features [38]. CHIME syndrome (MIM 280000), also known as Zunich Neuro-Ectodermal syndrome was found to be due to mutations in PIGL (MIM 605947). Individuals with CHIME syndrome present with colobomas, congenital heart defects, early onset migratory ichthyosiform dermatosis, IDD, and ear anomalies, including conductive and sensorineural hearing loss [43]. PIGT mutations cause congenital anomalies-seizures-hypotonia type 3 , with hypophosphatasia as key feature $[44,45]$. The wide spectrum of human conditions associated with mutations in PIG genes reflects their role in multiple developmental processes and resembles the diversity of clinical features associated with glycosylation pathways deficiencies [43].

A variety of clinical case descriptors have been applied to individuals with germline PIGA mutations (Table 1). However, given the varied clinical spectrum reported to date, it appears that the multi-system roles of GPIanchored proteins and private nature of most of the PIGA mutations identified will preclude the definition of a common feature set. To unify further reports on this intriguing condition, we advocate for the use of 'PIGA deficiency'.

Careful patient phenotyping will continue to shed light on the (patho-) physiologic roles of PIGA deficiency; for example, its relation with mitochondrial structure and function. We are the first to report severely reduced amount of mitochondrial complexes (specifically I and $\mathrm{V})$, but other mitochondrial defects have been reported in PIGA mutations: e.g. 'disorganized mitochondria' in FCC syndrome [16] and 'abnormal ATP production' in a 
patient with accelerated linear growth and obesity [17]. In fact, recent publications show that several mitochondrial membrane proteins are either modified with GPI anchor addition or associated with GPI anchored proteins, a process required for their proper function [46]. Therefore, it is of great interest to test patients with the PIGA mutations for mitochondrial defects and vice versa, to test the patients with unexplained mitochondrial phenotypes for potential PIGA mutations, especially in the presence of features described here.

\section{Conclusions}

Based on the patient descriptions published to date, intractable, infantile onset epilepsy with suppression burst and/or hypsarrhythmia in patients with X-linked IDD of unknown etiology should prompt clinicians to consider germline mutations in the PIGA, particularly in a patient with elevated serum alkaline phosphatase. The additional presence of dysmorphic facial features, CNS abnormalities, hypotonia, heart defects, dyslipidemia/lipoprotein lipase deficiency, or signs of intra-myelin edema on brain MRI, may increase the likelihood of mutations in PIGA specifically, and PIG family members in general. Flow cytometry of blood granulocytes has also proven a useful test for levels of GPI-anchored proteins expression in patients with PIGA mutations $[7,15,16,18]$.

\begin{abstract}
Abbreviations
PIGA: Phosphatidylinositol glycan biosynthesis class A protein GPI: Glycosylphosphatidylinositol; PIG: Phosphatidylinositol glycan biosynthesis protein; PI: Phosphatidylinositol; PNH: Paroxysmal nocturnal hemoglobinuria; GlcNAc: N-acetylglucosamine; UDP-GlcNAc: UDP-N-acetylglucosamide; WES: Whole Exome Sequencing; MSUD: Maple syrup urine disease; MCAHS2: Multiple congenital anomalies-hypotonia-seizures syndrome 2; FCCS: Ferro-Cerebro-Cutaneous syndrome; BNG: Blue Native Gel; OFC: Occipital frontal circumference; NAA: N-Acetylaspartic acid; TORCH: Toxoplasmosis, rubella, cytomegalovirus, herpes simplex, and HIV; IDD: Intellectual developmental disorder; TIDEX: Treatable Intellectual Disability Endeavour eXome sequencing; CNV: Copy number variation; CADD: Combined Annotation-Dependent Depletion; SIFT: Sorting Intolerant From Tolerant; AR: Androgen Receptor; XCI: X-Chromosome inactivation; XLIDD: X-linked intellectual developmental disability; GPIHBP1: GPI-anchored high-density lipoprotein binding protein 1; HPMRS: Hyperphosphatasia Mental Retardation syndrome; PTC: Premature termination codon.
\end{abstract}

\section{Competing interests}

The authors declare that they have no competing interests.

\section{Authors' contributions}

MTG: performed bioinformatics analysis and identified PIGA mutation; reviewed and summarized the literature, and drafted the manuscriptl: GS: participated in data analysis and interpretation as well as drafting and revision of the manuscript: SS: clinical case description, clinical diagnostic management, enrolment in WES research project, critical editing and revision of the manuscript: MVA: described the dysmorphologic exam, performed diagnostic investigations and contributed to the drafting and critical edits of the manuscripts: JR: designed and performed the functional analyses (CD109 measurements and Western Blot on fibroblasts): CS: contributed to the bio-informatic analysis: RB: contributed to the phenotypic description of the case, with focus on epilepsy and neuro-imaging results: TO: provided genetic counselling to the family, contributed to data collection and provided critical manuscript edits: ML: collected phenotypical and testing data, contributed to the case description and extracted qualitative data from printed and electronic records: BS: contributed to the case description and provided manuscript edits and revisions: CJR: performed targeted Sanger sequencing for all candidate variants identified via WES in this family, provided critical edits to the manuscript: WR: performed and interpreted X-inactivation studies, contributed to the manuscript with subsequent critical edits: WW: Supervised the bio-informatic analysis and pipeline creation: AR: interpretation and description of ten euro-imaging findings, preparation figures, critical editing and revision of the manuscript: CVK: spearheaded the conception and design of the study, acquisition of data, and coordinated data analysis and interpretation, as well as drafting and revision of the manuscript. All authors read and approved the final manuscript.

\section{Acknowledgments}

We are indebted to the patient and his family for participation in this study; Dr. S. Miller, Dr. S. Mahmutoglu and Dr. P. Louie for their contributions to clinical management of the patient; Dr. Maria Penaherrera and Ms. Ruby Jiang for X-inactivation studies; Mrs. X. Han for Sanger sequencing; Dr. M. Thomas for consenting and data management; Mrs. M. Higginson for DNA extraction and sample handling; Mr. D. Arenillas and Mr. M. Hatas for systems support, and Mrs. D. Pak for research management support (University of British Columbia). Dr. R. Hegele (University of Western Ontario, Canada) for $L P L$ molecular analysis. We are also grateful to the anonymous reviewers; their thoughtful comments and suggestions helped us strengthen the manuscript.

This work was supported by funding from the B.C. Children's Hospital Foundation as "1st Collaborative Area of Innovation" (www.tidebc.org); Genome BC (SOF-195 grant); BC Clinical Genomics Network (\#00032 grant), and the Canadian Institutes of Health Research (\#301221 grant). Informatics infrastructure supported by Genome BC and Genome Canada (ABC4DE Project). Dr. C. van Karnebeek is a recipient of the Michael Smith Foundation for Health Research Scholar Award.

\section{Author details}

${ }^{1}$ Centre for Molecular Medicine and Therapeutics, Vancouver, Canada. ${ }^{2}$ Department of Medical Genetics, University of British Columbia, Vancouver, Canada. ${ }^{3}$ Treatable Intellectual Disability Endeavour in British Columbia, Vancouver, Canada. ${ }^{4}$ Division of Biochemical Diseases, Department of Pediatrics, BC Children's Hospital, University of British Columbia, Vancouver, Canada. ${ }^{5}$ Division of Hematology, Oncology \& BMT, Department of Pediatrics, BC Children's Hospital, University of British Columbia, Vancouver, Canada. ${ }^{6}$ Biochemical Genetics Laboratory, Department of Pathology, BC Children's Hospital, University of British Columbia, Vancouver, Canada. ${ }^{7}$ Child \& Family Research Institute, Vancouver, BC, Canada. ${ }^{8}$ Department of Paediatric Neurology, Children's Hospital Oxford, John Radcliffe Hospital, Oxford, UK. ${ }^{9}$ Department of Neuroradiology, Istituto Giannina Gaslini, Via Gerolamo Gaslini 5, I-16147 Genoa, Italy.

Received: 17 December 2014 Accepted: 18 February 2015 Published online: 27 February 2015

\section{References}

1. Fujita M, Kinoshita T. GPI-anchor remodeling: potential functions of GPI-anchors in intracellular trafficking and membrane dynamics. Biochim Biophys Acta. 1821;2012:1050-8.

2. Kawagoe K, Kitamura D, Okabe M, Taniuchi I, Ikawa M, Watanabe T, et al. Glycosylphosphatidylinositol-anchor-deficient mice: implications for clonal dominance of mutant cells in paroxysmal nocturnal hemoglobinuria. Blood. 1996:87:3600-6.

3. Nozaki M, Ohishi K, Yamada N, Kinoshita T, Nagy A, Takeda J. Developmental abnormalities of glycosylphosphatidylinositol-anchor-deficient embryos revealed by Cre/loxP system. Lab Investig J Tech Methods Pathol. 1999:79:293-9.

4. Hazenbos WLW, Clausen BE, Takeda J, Kinoshita T. GPI-anchor deficiency in myeloid cells causes impaired FcgammaR effector functions. Blood. 2004;104:2825-31.

5. Almeida AM, Murakami Y, Layton DM, Hillmen P, Sellick GS, Maeda Y, et al. Hypomorphic promoter mutation in PIGM causes inherited glycosylphosphatidylinositol deficiency. Nat Med. 2006;12:846-51.

6. Ueda Y, Yamaguchi R, Ikawa M, Okabe M, Morii E, Maeda Y, et al. PGAP1 knock-out mice show otocephaly and male infertility. J Biol Chem. 2007;282:30373-80. 
7. Belet S, Fieremans N, Yuan X, Van Esch H, Verbeeck J, Ye Z, et al. Early frameshift mutation in PIGA identified in a large XLID family without neonatal lethality. Hum Mutat. 2014;35:350-5.

8. Bessler M, Mason PJ, Hillmen P, Miyata T, Yamada N, Takeda J, et al. Paroxysmal nocturnal haemoglobinuria $(\mathrm{PNH})$ is caused by somatic mutations in the PIG-A gene. EMBO J. 1994;13:110-7.

9. Ware RE, Rosse WF, Howard TA. Mutations within the Piga gene in patients with paroxysmal nocturnal hemoglobinuria. Blood. 1994;83:2418-22.

10. Bessler M, Schaefer A, Keller P. Paroxysmal nocturnal hemoglobinuria: insights from recent advances in molecular biology. Transfus Med Rev. 2001;15:255-67.

11. Brodsky RA. Narrative review: paroxysmal nocturnal hemoglobinuria: the physiology of complement-related hemolytic anemia. Ann Intern Med. 2008;148:587-95.

12. Brodsky RA. How I treat paroxysmal nocturnal hemoglobinuria. Blood. 2009;113:6522-7.

13. Dunn DE, Yu J, Nagarajan S, Devetten M, Weichold FF, Medof ME, et al. A knock-out model of paroxysmal nocturnal hemoglobinuria: Pig-a(-) hematopoiesis is reconstituted following intercellular transfer of GPI-anchored proteins. Proc Natl Acad Sci U S A. 1996;93:7938-43.

14. Chen G, Ye Z, Yu X, Zou J, Mali P, Brodsky RA, et al. Trophoblast differentiation defect in human embryonic stem cells lacking PIG-A and GPI-anchored cell-surface proteins. Cell Stem Cell. 2008;2:345-55.

15. Johnston JJ, Gropman AL, Sapp JC, Teer JK, Martin JM, Liu CF, et al. The phenotype of a germline mutation in PIGA: the gene somatically mutated in paroxysmal nocturnal hemoglobinuria. Am J Hum Genet. 2012;90:295-300.

16. Swoboda KJ, Margraf RL, Carey JC, Zhou H, Newcomb TM, Coonrod E, et al. A novel germline PIGA mutation in Ferro-Cerebro-Cutaneous syndrome: a neurodegenerative $X$-linked epileptic encephalopathy with systemic ironoverload. Am J Med Genet A. 2014;164A:17-28.

17. Van der Crabben SN, Harakalova M, Brilstra EH, van Berkestijn FMC, Hofstede FC, van Vught AJ, et al. Expanding the spectrum of phenotypes associated with germline PIGA mutations: a child with developmental delay, accelerated linear growth, facial dysmorphisms, elevated alkaline phosphatase, and progressive CNS abnormalities. Am J Med Genet A. 2014;164A:29-35.

18. Kato M, Saitsu H, Murakami Y, Kikuchi K, Watanabe S, lai M, et al. PIGA mutations cause early-onset epileptic encephalopathies and distinctive features. Neurology. 2014;82:1587-96.

19. Shyr C, Tarailo-Graovac M, Gottlieb M, Lee J, van Karnebeek C, Wasserman WW. FLAGS, frequently mutated genes in public exomes. BMC Med Genomics. 2014;7:64

20. Kircher M, Witten DM, Jain P, O'Roak BJ, Cooper GM, Shendure J. A general framework for estimating the relative pathogenicity of human genetic variants. Nat Genet. 2014:46:310-5.

21. Adzhubei IA, Schmidt S, Peshkin L, Ramensky VE, Gerasimova A, Bork P, et al. A method and server for predicting damaging missense mutations. Nat Methods. 2010;7:248-9

22. Kumar P, Henikoff S, Ng PC. Predicting the effects of coding non-synonymous variants on protein function using the SIFT algorithm. Nat Protoc. 2009:4:1073-81.

23. Notredame C, Higgins DG, Heringa J. T-Coffee: a novel method for fast and accurate multiple sequence alignment. J Mol Biol. 2000;302:205-17.

24. Allen RC, Zoghbi HY, Moseley AB, Rosenblatt HM, Belmont JW. Methylation of Hpall and Hhal sites near the polymorphic CAG repeat in the human androgen-receptor gene correlates with X chromosome inactivation. Am J Hum Genet. 1992;51:1229-39.

25. Beever C, Lai BPY, Baldry SEL, Peñaherrera MS, Jiang R, Robinson WP, et al. Methylation of ZNF261 as an assay for determining $X$ chromosome inactivation patterns. Am J Med Genet A. 2003;120A:439-41.

26. Adzhubei I, Jordan DM, Sunyaev SR: Predicting functional effect of human missense mutations using PolyPhen-2. Curr Protoc Hum Genet Editor Board Jonathan Haines Al 2013, Chapter 7:Unit7.20.

27. Chiyonobu T, Inoue N, Morimoto M, Kinoshita T, Murakami Y. Glycosylphosphatidylinositol (GPI) anchor deficiency caused by mutations in PIGW is associated with West syndrome and hyperphosphatasia with mental retardation syndrome. J Med Genet. 2014;51:203-7.

28. Claes S, Devriendt K, Lagae L, Ceulemans B, Dom L, Casaer P, et al. The X-linked infantile spasms syndrome (MIM 308350) maps to Xp11.4-Xpter in two pedigrees. Ann Neurol. 1997:42:360-4.
29. Di Rocco M, Biancheri R, Rossi A, Allegri AEM, Vecchi V, Tortori-Donati P. MRI in acute intermittent maple syrup urine disease. Neurology. 2004;63:1078.

30. Tortori-Donati P, Rossi A. Pediatric Neuroradiology. Berlin, Heidelberg: Springer Berlin Heidelberg; 2005.

31. Rossi A, Biancheri R. Magnetic resonance spectroscopy in metabolic disorders. Neuroimaging Clin N Am. 2013;23:425-48.

32. Van der Knaap MS, Valk J, de Neeling N, Nauta JJ. Pattern recognition in magnetic resonance imaging of white matter disorders in children and young adults. Neuroradiology. 1991;33:478-93.

33. Yamamoto $H$, Onishi M, Miyamoto N, Oki R, Ueda H, Ishigami M, et al. Novel combined GPIHBP1 mutations in a patient with hypertriglyceridemia associated with CAD. J Atheroscler Thromb. 2013;20:777-84.

34. Manuvakhova M, Keeling K, Bedwell DM. Aminoglycoside antibiotics mediate context-dependent suppression of termination codons in a mammalian translation system. RNA N Y N. 2000;6:1044-55.

35. Cassan M, Rousset JP. UAG readthrough in mammalian cells: effect of upstream and downstream stop codon contexts reveal different signals. BMC Mol Biol. 2001;2:3.

36. McCaughan KK, Brown CM, Dalphin ME, Berry MJ, Tate WP. Translational termination efficiency in mammals is influenced by the base following the stop codon. Proc Natl Acad Sci U S A. 1995:92:5431-5.

37. Tate WP, Poole ES, Horsfield JA, Mannering SA, Brown CM, Moffat JG, et al. Translational termination efficiency in both bacteria and mammals is regulated by the base following the stop codon. Biochem Cell Biol Biochim Biol Cell. 1995;73:1095-103

38. Krawitz PM, Schweiger MR, Rödelsperger C, Marcelis C, Kölsch U, Meisel C, et al. Identity-by-descent filtering of exome sequence data identifies PIGV mutations in hyperphosphatasia mental retardation syndrome. Nat Genet. 2010;42:827-9.

39. Krawitz PM, Murakami Y, Hecht J, Krüger U, Holder SE, Mortier GR, et al. Mutations in PIGO, a member of the GPI-anchor-synthesis pathway, cause hyperphosphatasia with mental retardation. Am J Hum Genet. 2012;91:146-51.

40. Hansen L, Tawamie H, Murakami Y, Mang Y, Ur Rehman S, Buchert R, et al. Hypomorphic mutations in PGAP2, encoding a GPI-anchor-remodeling protein, cause autosomal-recessive intellectual disability. Am J Hum Genet. 2013;92:575-83.

41. Krawitz PM, Murakami Y, Rieß A, Hietala M, Krüger U, Zhu N, et al. PGAP2 mutations, affecting the GPI-anchor-synthesis pathway, cause hyperphosphatasia with mental retardation syndrome. Am J Hum Genet. 2013;92:584-9.

42. Howard MF, Murakami Y, Pagnamenta AT, Daumer-Haas C, Fischer B, Hecht J, et al. Mutations in PGAP3 impair GPI-anchor maturation, causing a subtype of hyperphosphatasia with mental retardation. Am J Hum Genet. 2014;94:278-87.

43. Ng BG, Hackmann $\mathrm{K}$, Jones MA, Eroshkin AM, He P, Wiliams R, et al. Mutations in the glycosylphosphatidylinositol gene PIGL cause CHIME syndrome. Am J Hum Genet. 2012;90:685-8.

44. Kvarnung M, Nilsson D, Lindstrand A, Korenke GC, Chiang SCC, Blennow E, et al. A novel intellectual disability syndrome caused by GPI anchor deficiency due to homozygous mutations in PIGT. J Med Genet. 2013:50:521-8

45. Nakashima M, Kashii H, Murakami Y, Kato M, Tsurusaki Y, Miyake N, et al. Novel compound heterozygous PIGT mutations caused multiple congenital anomalies-hypotonia-seizures syndrome 3. Neurogenetics. 2014;15:193-200.

46. Zhao P, Nairn AV, Hester S, Moremen KW, O'Regan RM, Oprea G, et al. Proteomic identification of glycosylphosphatidylinositol anchor-dependent membrane proteins elevated in breast carcinoma. J Biol Chem. 2012;287:25230-40. 